\title{
Consumer Purchase Behaviour for Green Products
}

\author{
Vinod Sharma ${ }^{1}$, J. Sonwalkar ${ }^{2}$, Maohar Kapse ${ }^{3}$
}

\begin{abstract}
:
Purpose: The concern for climate change and global warming is increasing at global level which results in stimulating the interest of firms toward environmental protection and sustainable development. Many firms have started developing green products to meet the demand of environmentally conscious consumers. These firms are now interested in finding the determinants of environmentally conscious consumers' behaviour in order to develop effective marketing strategy to ensure the green purchase commitments. Methodology: Demographic factors, psychographic factors, environmental awareness, environmental concern, price \& quality of the green products, Perceived Consumer Effectiveness (PCE), environmental attitude, information, promotional activity, and availability, are major factors in motivating one's behavioural change to engage in environmental behaviour. These factors have been tested in the past, but they have never been tested together in the context of green purchase behaviour of consumers in Central India. Therefore, this paper reviews the conceptual and empirical literatures of the abovementioned variables in explaining the green purchase behaviour. To indentify the factors which influence the consumer purchase behaviour for green products, factor analysis has been used. Data Collection: And convenient sampling method was used to collect the data from the five major cities of Madhya Pradesh. Over 650 questionnaires were circulated out of which a total of 390 questionnaires were considered for the final research purpose with $5 \%$ error of margin and $5 \%$ level of significance. Finding: The research has came out with seven major factors, (1. Awareness \& Concern, 2. Price \& Quality, 3. PCE, 4. Information, 5. Attitude, 6. Promotional activity, and 7. Information), which influence the green purchase behaviour in central India.
\end{abstract}

\section{Key Words:}

Green Purchase Behaviour, Environmentally Conscious Consumers, Environmental Concern, Environmental Knowledge, Environmental Attitude

JEL Classification: H41, M31, Q21, Q56

\footnotetext{
${ }^{1}$ Assistant Professor, Medicaps Institute of Technology \& Management, Indore

${ }^{2}$ Professor of Marketing, Institute of Management Studies, DAVV, Indore

${ }^{3}$ Associate Professor, Shri Vaishnav Institute of Management, Indore
} 


\section{Introduction}

Though Indian government has not made it mandatory for corporate social responsibility but to survive in today's competitive business environment, where consumers are going very concern about the environmental issues, both profit oriented and socially responsible firms have started adopting the concept of green marketing and address the environmental issues as a source of competitive advantage (Tan, 2011; Roberts, 1996). These firms have started developing and promoting the green products to meet the demand of environmentally conscious consumers (Tan, 2011; Kassaye, 2001; Polonsky and Kilboume, 2005). Even environmental or green marketing, a strategic marketing approach is a recent focus in business endeavors (Chen and Chai, 2010; Ottman, 1998).

Increasing focus on environmental issues can be seen as an indication that concerns for the environment have emerged as a potential strategic concern for businesses (Polonsky and Kilboume, 2005; Menon and Menon, 1997). The belief is that the consumers' pro-environmental concern is one of the determinants of their 'green buying' behaviour i.e., buying and consuming products that are environmentally beneficial (Mainieri et al., 1997).

Green marketing is considered as one of the major trends in modem businesses (Kassaye, 2001; McDaniel and Rylander, 1993; Pujari and Wright, 1996). Environmental ecological or green marketing are similar terms used in literature, is a way to use the environmental benefits of a product or service to promote sales. According (Belz and Peattie, 2008), green marketing and environmental marketing in the late 1980's focused on green consumers who would be willing to pay premium prices for more environmentally friendly products. Many consumers choose products that do not damage the environment over less environmentally friendly products, even if they cost more. With green marketing, advertisers focus on environmental benefits to sell products such as biodegradable diapers, energy-efficient light bulbs, and environmentally safe detergents. Green marketing encourages consumers to use ecofriendly products and manufacturers to develop more environmentally beneficial products (Tan, 2011).

To influence the interest of consumer for purchasing green products, green advertising messages must be informative and persuasive enough in obtaining the desirable targeted business outcomes (Belz and Peattie, 2008). Peattie (2001), identified that the advertising claims such as 'eco-friendly' is the most common terms being used in the market but its effectiveness in convincing green purchase action is still insignificant. As a result, firms have started identifying and understanding the factors which consumers' purchase behaviour for green product in order to deliver an effective and persuasive advertisement in their marketing and communication strategies (Chen and Chai, 2010; Tan, 2011). 
As India is the fastest developing country, facing great challenges in ensuring a balance between development and environmental sustainability. Any remedy to preserve the Earth's resources requires not only a radical rethink and action of government and business, but also the immediate changes in attitudes and buying behaviour of consumers to contribute to the sustainable and diminished use of nature resources (Nema, 2011).

Therefore, the purpose of this paper is to identify the factors influencing purchasing behaviour of consumer for green products. The structure of the paper is as follows: we first review the literature pertaining to the conceptual theories of variables. Second, identifying factors affecting the consumer purchase behaviour for green products through factor analysis in SPSS. This leads to the development of propositions for this study. Finally, the research objectives to be considered for future research undertaking in the context of consumer buying behaviour for green products are proposed.

\section{Review of Literature}

Businesses are globally coming up with the new responsibility of promoting sustainable development by preserving the limited natural resources and conserve them to meet the needs of the future generation. Continuous changes in natural resources and the over consumption has led to some realization about human responsibility towards nature. This realization has led to development of eco-friendly consumption patterns or green purchase behaviour among consumers.

Green purchase behaviour is one Green purchase behaviour of the pro-environmental behaviours (Chan, 2001; Kim, 2002; Kim and Choi, 2003; 2005; Mostafa, 2007). It refers to the purchasing and consuming products that have minimal impacts on environment (Mainieri, et al, 1997). Obviously, firms are willing to operate in a sustainable manner but provided by doing so could enable them to gain competitive advantage. However, it is still questionable on the green purchase commitment if there are sufficient green products available in the market (Chan, 1996) as the share of green market activities is still lacking (Peattie, 2001; Kalafatis, Pollard, et al, 1999; McCarty \& Shrum,, 1995).

As a result, it is essential to encourage and promote the environmental responsible consumption behaviour such as purchasing the green products to minimize the direct and indirect impacts from the individual consumption decision on the environmental degradation, especially in the trend of urbanization, changing lifestyle as well as increasingly number of affluence people in India. 


\subsection{Environmental awareness \& concern}

Consumers who have awareness and concern for the essentials of environmental issues are known as green consumers (Soonthorsmai, 2007). Roberts (1996) indicated that environmentally conscious consumers and consumers who believe the specific ecological activities can improve the environmental issues are more likely to perform green consumer behaviors. Krause (1993) in his research found that consumers were becoming more concerned about their everyday habits and the impact on the environment. The outcome of the study this is that some of the consumers translated their environmental concern into actively purchasing green products commitment (Martin and Simintiras, 1995). Some studies suggest that there is a positive relationship between environmental concern and green buying behaviour (Arbuthnot \& Lingg, 1975). To extend the discussion we can say that;

\subsection{Environmental attitude}

Allport (1935) defined attitude as: "A mental and neural state of readiness, which exerts a directing, influence upon the individual's response to all objects and situations with which it is related". According to Schultz and Zelezny (2000), "attitudes of environmental concern are rooted in a person's concept of self and the degree to which an individual perceives him or herself to be an integral part of the natural environment". Schultz et al., (2004) defined environmental attitude as "the collection of beliefs, affect, and behavioural intentions a person holds regarding environmentally related activities or issues". Milfont (2007) defined the environmental attitude as the "psychological tendency that is expressed by evaluating perceptions of or beliefs regarding the natural environment, including factors affecting its quality, with some degree of favour or disfavour". In conclusion we can say that, attitude represents what consumers like and dislike (Blackwell et al., 2006) and consumers' product purchasing decisions are often based on their environmental attitudes (Irland, 1993; Schwepker and Cornwell, 1991). Schultz and Zelezny (2000); (Blackwell et al., 2006); Milfont (2007)

\subsection{Perceived Consumer Effectiveness (PCE)}

Perceived Consumer Effectiveness (PCE) refers to the extent to which individuals believe that their actions make a difference in solving a problem (Kim, 2005; Ellen et al., 1991). Initially, PCE was measured as an element of personality variable to predict ecological concern (Kinnear et al., 1974) and ecological consumption responsible patterns (Balderjahn, 1988; Berger and Corbin, 1992; Tesser and Shaffer 1990).

Ellen et al. (1991) revealed that PCE for environmental issues are also different from environmental concerns or attitudes and make a unique contribution to the prediction of environmentally conscious behaviours such as green purchase. Consumer concerns about the environmental issues might not easily translate into pro-environmental behaviours; however, individuals with a strong belief that their environmentally 
conscious behaviour will result in a positive outcome are more likely to engage in such behaviours in support of their concerns for the environment. Accordingly, selfefficacy beliefs may influence the likelihood of performing green purchase behaviour (Tan and Lau, 2011; Kim, 2005).

Brown (1979) and Thompson (1981) concluded that PCE is determined by knowledge as well as direct and indirect experiences and varies with individuals as their personal knowledge and experiences differ. On other hand, Straughan and Roberts (1999) examined that PCE as an attitudinal variable to predict environmental behaviour. They found that PCE was a strong attitudinal variable to predict ecologically conscious consumer behaviour (EECB) which explained $33 \%$ of the variation in ECCB. In addition, Kim and Choi (2003) concluded that PCE have different impacts on different types of pro-environmental behaviour and an indirect effect on green purchase behaviour via environmental attitudes. It supported the notion proposed by Ellen et al. (1991) that PCE should be used to predict specific types of pro-environmental behaviour and not the general pro-environmental behaviour.

Further research by Kim and Choi (2005) also confirmed the role of PCE as a predictor on green purchase behaviour. Webb et al. (2008) reported that when consumers believed that their actions made a difference; they would be more likely to be influenced by the environmental impact in their purchase and usage decisions to recycle. In their study, the PCE scale was found to be a key variable associated with socially responsible behaviour. Another research conducted by Tan and Lau (2011) found that the PCE is significantly related to the green purchase behaviour.

\subsection{Marketing mix}

Roper Organization Inc. (1990) conducted a research to examine the impact of green marketing efforts on the implementation of green products and services. In a study on the American consumer's environmental behaviours and attitudes, found some of the following marketing mix related reasons for not behaving in an environmentallyfriendly manner;

- The green products were not functionally superior;

- The price of the green products were too exclusive;

- The promotional activities were not very influential and even the labels claiming that the product was environmentally-safe were not believable;

- The green products were not extensively available so it was too difficult to find them.

Mostafa, (2007) identified in his research that, the promotion and distribution of green products give awareness to the consumer's for the selection and availability of green alternatives. This awareness, however, does not always lead to ecologically-friendly 
consumption decisions. A recent survey of conducted by Business Standard (2011) on Indian consumer's, showed that majority of the respondents interviewed indicated that they would like to know more about the environmental friendly products and the products should be easily available.

Ottman (1992) found that, consumers purchase green products when their primary needs and wants for quality, availability, convenience, performance, and affordability are met. Consumers also purchase green products when they realized that green products can help to solve the environment problems. The researcher and environmentalist belief that through purchasing environmental friendly products, with recyclable packaging consumers can take important steps to improve the quality of the environment (Abdul-Muhmim, 2007).

According to Mintel's latest report on green living, the environment remains a concern for the majority of Americans. More than one-third (35\%) of survey respondents say they would pay more for 'environmentally friendly' products (Chicago, 2010). Another survey conducted by Mckinsey, in 2007, on around 7,751 people in Brazil, Canada, China, France, Germany, India, United Kingdom, and the United States, which shows that 87 percent of consumers are aware and concerned about the environmental and social impact of the products they buy. But when it comes to actually buying green goods, no more than 33 percent of the consumers in our survey say they are ready to buy green products or they are purchasing.

\section{Methodology of the Study²}

A questionnaire was developed to study and identify the factors affecting the purchase behaviour of consumer for green products. To develop the questionnaire the study of Chen and Chai, 2010; Chan, 2001; Manafi, Hojabri, Hooman, Borousan and Khatibi, 2011, and Tan and Lau, 2011 has been considered. The questionnaire consists of 39 questions, which was divided in two parts. The first part consists of demographic features, which includes Age, Gender, Marital Status, Education, Profession, and Income. The second part consists of 27 variables which influence the purchase behaviour of consumers.

\subsection{The objectives of the study}

${ }^{2}$ Limitation and Scope for Future Study: This research is confined to cities of central India and there for needs to validated from the data collected from other parts of India. The scope for the study is limited to factors affecting the consumer purchase behaviour for green products which does not include factors like legal factor, government regulation and impact of WTO, etc.

Scope for future study: Further study may include responses from the consumers of other parts of India.A comparison of responses from the consumers of other countries may give interesting results. 
The main objective the research was to identify the factors affecting the consumer purchase behaviour for green products in Central India (Madhya Pradesh).

\subsection{Population of the study}

The population of Madhya Pradesh in 2011 survey was 72.597.565 (www.censusindia.gov.in). For the study data was collected from the five major cities of the state (Indore, Bhopal, Gwalior, Jabalpur, and Rewa). Over six hundred and fifty questionnaires were circulated for the data collection in the above mentioned cities out of which a total of three hundred and ninety questionnaires were considered for the final research purpose.

\subsection{Sample size}

The sample size for the study with 5\% error of margin and $5 \%$ level of significance is 385 as per the formula given by Krejcie and Morgan in their article (Krejcie and Morgan, 1970). A convenient sampling method was used to collect the data from the five major cities of Madhya Pradesh.

\subsection{Statistical data analysis}

In order to find the factors/components which influence the consumer purchases behavior for green products, factor analysis has been used. The statistical approach involves finding a way of condensing the information contained in a number of original variables into a smaller set of dimensions (factors) with a minimum loss of information is factor analysis.

Bartlett's test of Spericity is a test statistics used to examine whether factor analysis is applicable on the data set or not. In other words, the population correlation matrix is an identity matrix where each variable correlates perfectly with itself but has no correlation with other variables. A large value rejects the hypothesis and makes the factor analysis appropriate.

KMO measure of sampling is an index used to examine the appropriateness of the factor analysis. High value $(0.5-1.0)$ makes the factor analysis appropriate. From the Table 1 it is clear that factor analysis is appropriate since both the criterion are satisfied by the data

Table 1: KMO and Bartlett's Test

\begin{tabular}{|l|l|l|}
\hline \multicolumn{2}{|l|}{$\begin{array}{l}\text { Kaiser-Meyer-Olkin Measure of Sampling } \\
\text { Adequacy. }\end{array}$} & .745 \\
\hline $\begin{array}{l}\text { Bartlett's Test of } \\
\text { Sphericity }\end{array}$ & Approx. Chi-Square & 3653.462 \\
\cline { 2 - 3 } & Df & 300 \\
\cline { 2 - 3 } & Sig. & .000 \\
\hline
\end{tabular}


From the Table 2 it is clear that the $62 \%$ of the variance is explained by the seven components

Table 2: Total Variance Explained

\begin{tabular}{|l|c|c|c|}
\hline \multirow{2}{*}{ Component } & \multicolumn{3}{|c|}{ Rotation Sums of Squared Loadings } \\
\hline & Total & \% of Variance & Cumulative \% \\
\hline 1 & 3.463 & 13.850 & 13.850 \\
\hline 2 & 2.323 & 9.294 & 23.144 \\
\hline 3 & 2.289 & 9.156 & 32.300 \\
\hline 4 & 2.232 & 8.927 & 41.227 \\
\hline 5 & 1.972 & 7.888 & 49.115 \\
\hline 6 & 1.878 & 7.512 & 56.627 \\
\hline 7 & 1.524 & 6.095 & 62.722 \\
\hline
\end{tabular}

Note: Extraction Method: Principal Component Analysis

The factors are rotated in order to find new factors that are easier to interpret. Here we have used varimax rotation. Varimax rotation tries to maximize the variance of each of the factors, so the total amount of variance accounted for is redistributed over the extracted factors. The Table 3 shows the rotated component matrix with the variables and there loadings

Table 3: Rotated Component Matrix (a)

\begin{tabular}{|c|c|c|c|c|c|c|c|c|}
\hline & \multicolumn{8}{|c|}{ Component } \\
\hline & 1 & 2 & 3 & 4 & 5 & 6 & 7 & 8 \\
\hline $\begin{array}{l}\text { I can write more than } \\
\text { three brand names } \\
\text { selling under the } \\
\text { green tag. }\end{array}$ & .781 & & & & & .303 & & \\
\hline $\begin{array}{l}\text { I have a thorough } \\
\text { knowledge about } \\
\text { green products. }\end{array}$ & .722 & & & & & & & \\
\hline $\begin{array}{l}\text { I purchase green } \\
\text { products because it is } \\
\text { considered to be a } \\
\text { status symbol. }\end{array}$ & .682 & & & & & .421 & & \\
\hline
\end{tabular}




\begin{tabular}{|c|c|c|c|c|c|c|c|c|}
\hline $\begin{array}{l}\text { I am extremely } \\
\text { worried about the } \\
\text { state of the world's } \\
\text { environment and } \\
\text { what it will mean for } \\
\text { my future. }\end{array}$ & .679 & & & & & & & \\
\hline $\begin{array}{l}\text { I am very much } \\
\text { concern about the } \\
\text { environment. }\end{array}$ & .666 & & .338 & & & & & \\
\hline $\begin{array}{l}\text { Mankind is severely } \\
\text { abusing the } \\
\text { environment. }\end{array}$ & .501 & .333 & & & & & & \\
\hline $\begin{array}{l}\text { Price is the major } \\
\text { concern for me to go } \\
\text { for green products. }\end{array}$ & .455 & .432 & & & & & .410 & .328 \\
\hline $\begin{array}{l}\text { Though I like to buy } \\
\text { green products but I } \\
\text { cannot afford them. }\end{array}$ & & .746 & & & & & & \\
\hline $\begin{array}{l}\text { I will switch to green } \\
\text { product if it is } \\
\text { available at the same } \\
\text { price compare to my } \\
\text { favourite brands. }\end{array}$ & & .590 & .468 & & & & & \\
\hline $\begin{array}{l}\text { Quality is one of the } \\
\text { most important } \\
\text { factors what } \\
\text { influences me for } \\
\text { purchase of green } \\
\text { products? }\end{array}$ & & .588 & & & & & .329 & \\
\hline $\begin{array}{l}\text { I may buy green } \\
\text { products provided it } \\
\text { is easily available. }\end{array}$ & & & .861 & & & & & \\
\hline $\begin{array}{l}\text { I am ready to buy } \\
\text { green products but I } \\
\text { don't know from } \\
\text { where to buy. }\end{array}$ & & & .672 & & .422 & & & \\
\hline $\begin{array}{l}\text { I may buy green } \\
\text { products provided I } \\
\text { have sufficient } \\
\text { information about it. }\end{array}$ & & & .583 & & & .314 & .319 & \\
\hline $\begin{array}{l}\text { I can protect the } \\
\text { environment by } \\
\text { buying the } \\
\text { environment friendly } \\
\text { products. }\end{array}$ & & & & .829 & & & & \\
\hline
\end{tabular}




\begin{tabular}{|c|c|c|c|c|c|c|c|c|}
\hline $\begin{array}{l}\text { There is not much } \\
\text { that I can do about } \\
\text { the environment. }\end{array}$ & & & & .826 & & & & \\
\hline $\begin{array}{l}\text { I feel I can help in } \\
\text { solving natural } \\
\text { resource problem by } \\
\text { conserving water and } \\
\text { energy. }\end{array}$ & & .461 & & .481 & .401 & & & \\
\hline $\begin{array}{l}\text { I may buy green } \\
\text { products but I am not } \\
\text { sure about the quality } \\
\text { of the product. }\end{array}$ & & & & & .820 & & & \\
\hline $\begin{array}{l}\text { I feel for } \\
\text { environment but I } \\
\text { don't have any } \\
\text { information about } \\
\text { the green products. }\end{array}$ & & & & & .684 & & & \\
\hline $\begin{array}{l}\text { I am satisfied with } \\
\text { the quality of green } \\
\text { products. }\end{array}$ & & .407 & & .383 & -.408 & .308 & & \\
\hline $\begin{array}{l}\text { I think green } \\
\text { products suits to my } \\
\text { life style also. }\end{array}$ & & & & & & .769 & & \\
\hline $\begin{array}{l}\text { I do recommend to } \\
\text { my friends and } \\
\text { family members to } \\
\text { buy green products }\end{array}$ & & & .417 & & -.316 & .536 & & \\
\hline $\begin{array}{l}\text { I am ready to pay } \\
\text { extra for the green } \\
\text { product. }\end{array}$ & .395 & -.329 & & & & .455 & & \\
\hline $\begin{array}{l}\text { Advertisement } \\
\text { influences me more } \\
\text { for purchasing green } \\
\text { products. }\end{array}$ & & & & & & & .738 & \\
\hline $\begin{array}{l}\text { I Feel I am more } \\
\text { respected for using } \\
\text { green products. }\end{array}$ & & & & & & & .488 & \\
\hline $\begin{array}{l}\text { It gives me better } \\
\text { feeling when I use } \\
\text { green products. }\end{array}$ & & & & & & & & .850 \\
\hline
\end{tabular}

Notes: Extraction Method: Principal Component Analysis.

Rotation Method: Varimax with Kaiser Normalization.A Rotation converged in 35 iterations. 


\section{Discussion of Findings}

From the factor analysis we can conclude that the $62 \%$ of the variance of the data is due to the seven factors which are as below:

Factor 1: Environmental Awareness \& Concern: The result confirms that the awareness and concern for the environment significantly influence of consumer purchase behaviour for green products in Central India, hence we can say that Environmental Awareness \& Concern is one of the factors which influence the consumer purchase behaviour for green products. This factor will result in enhanced emphasis on the communication strategies for influencing consumer purchase behaviour in favour of their products. This means only creating green products is not enough for companies but level of awareness among the consumers has to go us substantially for influencing their buying behaviour. There for communication strategies as well as budget have to be changed looking to the requirement of consumers and target to be covered.

This means that with the increase in consumer awareness the concern for environmental consequences will go up resulting in increased acceptance of green products. This result reiterate the points put forward by Grunert and Juhl (1995), Shim (1995), Aoyagi-Usui (2001), Kim and Choi (2003; 2005), Soonthorsmai (2007), and Tilikidou (2007).

Factor 2: Quality \& Price: The result confirms that quality and price of the green products has significant influence on consumer purchase behaviour. The result of this research leads to two types of conclusions regarding the pricing of green products. In our survey $32 \%$ consumers would not mind to pay premium for green products. In this case our findings, the Indian consumers seems to be consistent with the studies conducted by Accenture Global Auto Consumer Survey (2010), Chicago (2010), Abdul-Muhmim (2007) where consumers are ready to pay premium. While on other hand $59 \%$ consumers are not willing to pay anything extra for the green products. In this case our finding is consistent with the study conducted by Mckinsey (2007), Ottman (1992). But in both the cases consumers are not ready to compromise on the quality of the green products which is expected to be at par with existing products.

Factor 3: Availability: The study confirms that availability of the green product has a positive and significant influence on consumer purchase behaviour. This finding is showing the consistency with the Roper Organization Inc. (1990), Mostafa (2007), Business Standard (2011), and Ottman (1992). It has been observed that companies are generally selling the green products under the premium tag. This premium tag leads to the premium cost and hence, hampers the availability spectrum of the product 
because small retailers avoid storing the costly products. The more sales can be generated if companies make sure the easy and wide availability the green product.

Factor 4: Perceived Consumer Effectiveness (PCE): The result confirms that there is a significant and positive relationship between perceived consumer effectiveness (PCE) and consumer purchase behaviour for green products. It means that respondents who were engaged in buying environmentally friendly products do so because they believed that their actions or efforts by purchasing such products were able to help minimise the environment from further deterioration. To take the advantage of this positive relationship, company should try to convert highly committed consumers into PEC.

This finding was a supporter of previous findings that PCE can be used as a strong predictor on pro-environmental behaviour (Ellen et al., 1991; Berger and Corbin, 1992; Roberts, 1996; Straughan and Roberts, 1999; Lee and Holden, 1999; Kim, 2002; Kim and Choi, 2003; 2005; Tan and Lau, 2011; Webb et al., 2008). However, most importantly, besides acting as a predictor, several researchers have also confirmed its moderating roles between attitude and behaviour (Berger and Corbin, 1992; Kim, 2003; Gupta and Ogden, 2006; Laskova, 2007). However, the moderating role of PCE was not tested in this research.

Factor 5: Information: The result confirms that the information of the green product directly influence the consumer purchase behaviour for a green product. This means that companies are required to give more emphasis on the amount of information, type of information, media used for transfer of information and style and language used for the information to be communicated by the companies for the consumers for taking decisions in favour of purchasing green products. In nutshell, comprehensive information strategy is required to be built and deployed for promoting sale of green products to more and more consumers.

Factor 6: Environmental Attitude: As per the finding, there is a significant and positive relationship between environmental attitude and consumer purchase behaviour for green products. This finding was consistent with the result from Mainieri et al. (1997), Irland (1993), Schwepker and Cornwell (1991), Schultz and Zelezny (2000), Blackwell et al. (2006), Milfont (2007). Hence we can say that Environmental Attitude is one of the factors which influence the consumer purchase behaviour for green products.

Attitude plays an important in selecting green products in comparison to non green products. Building attitude will result in positive purchase behaviour. There for companies should make conscious efforts for building positive attitude towards environmental friendly products. And this can be done by running environment education program. 
Factor 7: Promotional Activity: The study confirms that the promotional activities of the organization for green products have a significant influence on consumer purchase behaviour. Studies conducted by Roper Organization Inc. (1990), Mostafa (2007), and Business Standard (2011) identified in their research that, the promotional activities of the organization for the green products increases the awareness and knowledge of the consumer. As literature has confirmed that this increased knowledge and awareness creates the concern for the environment and ultimately the concern for the environment may lead to the behavioural change in the customer. This means that green product manufacturers are required to put greater emphasis on promotional aspects which may increase their budget and cost of acquiring customers. But in long run green products will be prefer once they are accepted by the consumers.

\section{Conclusion}

As per the finding, there are seven factors which influence the consumer purchase behaviour for the green product in Central India. These seven factors are environmental awareness and concern, quality and price, availability, perceived consumer effectiveness (PCE), information, environmental attitude, and promotional activity.

The consumer purchase behaviour for green product is different from the conventional product purchase related behaviour. Now firms are required to decide on the viability of entering and expanding operations in the green markets. They are also required to develop an understanding of the factors affecting the consumer purchase behaviour so that they create better communication strategies and position their green brand in the appropriate target market in order to create a better customer value, while preserving the environment. Moreover, advertising messages need to be convincing enough to arouse the green purchase actions and commitment which will help in motivating the behavioural change of consumers to shift from buying conventional products to environmentally friendly products.

This research has identified that environmental attitude plays very role in behavioural change. But it does not guarantee the actual purchase. So it is important for the organizations to increase the level of awareness on the environmental issues through different media. This awareness and knowledge will arouse the fear and threat of environmental deterioration on the health and well-being. This fear will lead to concern and will increase the chances of change in behaviour for actual purchase green products. Moreover, firms also require to make sure the quality, price and availability of the green products. The higher perceived consumer effectiveness helps in solving the environmental problems while lower perceived consumer effectiveness will result indifferent buying behaviour of green products. 


\section{References}

Allport, G.W. (1935), Attitudes: In a handbook of social psychology, Worcester, MA, Clark University Press.

Abdul-Muhmin, A.G. (2007), "Exploring consumers' willingness to be environmentally friendly", International Journal of Consumer Studies, 31, pp. 237-247.

Balderjahn, I. (1988), Personality variables and environmental attitudes as predictors of ecologically responsible consumption patters. Journal of Business Research, 17: 51-56.

Berger, I.E. and Corbin, R.M. (1992), "Perceived consumer effectiveness and faith in others as moderators of environmentally responsible behaviours", Journal of Public Policy and Marketing, 11: 79-89.

Blackwell R.D., Miniard, P.W., \& Engel, J.F. (2001), Consumer Behaviour (9th ed.), New York, Harcourt College Publishers.

Blackwell, R.D., Miniard, P.W. and Engel, J.F. (2006), Consumer behavior (10th edition), Thomson Learning, South Western.

Booi-Chen, T. and Teck-Chai, L. (2011), "Green Purchase Behavior: Examining the Influence of Green Environmental Attitude, Perceived Consumer Effectiveness and Specific Green Purchase Attitude", Australian Journal of Basic and Applied Sciences, 5(8): 559-567, 1991-8178

Booi-Chen, T. (2011), "The Roles of Knowledge, Threat, and PCE on Green Purchase Behaviour", International Journal of Business and Management, Vol. 6, No. 12, pp. 1833-3850

Booi-Chen, T. and Teck-Chai, L. (2010), "Attitude towards the environment and Green Products: Consumers' Perspective", Management Science and Engineering Vol. 4, No. 2, 2010, pp. 27-39, pp. 1913-0341

Brown, G. and Haris, C. (1992), "The US forest service: Toward the new resource management paradigm?”, Society and Natural Resources, 5, pp. 231-245.

Chan, R.Y.K., (2001), "Determinants of Chinese consumers' green purchase behavior." Psychology and Marketing, 18(4): 389-413.

Chitra, K. (2007), "In Search of the green consumers: A perceptual study", Joumal of Services Research, 7(1), pp. 173-191.

Ellen, P.M., Wiener, J.L. and Cobb-Walgren, C. (1991), "The role of perceived consumer effectiveness in motivating environmentally conscious behaviors." Journal of Public Policy and Marketing, 10: 102-117.

Gupta, S. and Odgen, D.T. (2006), "The attitude-behavior gap in environmental consumerism”, APUBEF Proceedings-Fall.

Irland, L.C. (1993), "Wood producers face green marketing era: Environmentally Sound Products", Wood Technology, pp. 120 -134.

Kalafatis, S.P., Pollard, M., East, R. and Tsogas, M.H. (1999), "Green marketing and Ajzen's Theory of Planned Behavior: A cross-market examination", Journal of Consumer Marketing, 16, pp. 441-460.

Kalafatis S.P., Pollard, M., East, R., Tsogas, M.H. (1999), "Green marketing and Ajzen's theory of planned behaviour: A cross-market examination", The Journal of Consumer Marketing, Vol. 16 (5), pp. 441-460.

Kassaye, W.W. (2001), “Green dilemma”, Marketing Intelligence \& Planning, 19 (6), 444-55. 
Ottman, J. (1992), “Sometimes consumers will pay more to go green", Marketing News (July 6), p. 16.

Kim, Y. (2002), The impact of personal value structures on consumer pro-environmental attitudes, behaviours and consumerism: A cross-cultural study, Unpublished doctoral dissertation, College of Communication Arts and Sciences, Michigan State University.

Kim, Y. and Choi, S.M. (2003), "Antecedents of pro-environmental behaviors: An examination of cultural values, self-efficacy, and environmental attitudes", International Communication Association, Marriott Hotel, available at: www.allacademic.com/ meta/p111527_index.html.

Kim, Y. and Choi, S.M. (2005), “Antecedents of green purchase behavior: An examination of collectivism, environmental concern and PCE", Advances in Consumer Research, 32: 592-599.

Kinnear, T.C., Taylor, J.R. and Ahmed, S.A. (1974), "Ecologically concerned consumers: Who are they?", Journal of Marketing, 11: 20-24.

Kohut, A., \& Shriver, J. (1989), "Environment regaining a foothold on the national agenda", Gallup Report, p. 285.

Krejcie and Morgan, (1970), "Determining Sample Size for Research Activities", Educational and Psychological Measurement, Vol. 30, pp. 607-610.

Krause, D. (1993), "Environmental consciousness: An empirical study", Journal of Environment and Behavior, 25(1), pp. 126-42.

Laskova, A., (2007), "Perceived consumer effectiveness and environmental concerns", Proceedings of the $13^{\text {th }}$ Asia Pacific Management Conference, Melbourne, Australia, pp. 206-209.

Mainieri, T., Barnett, E., Valdero, T., Unipan, J., and Oskamp, S. (1997), “Green buying: The influence of environmental concern on consumer behavior", Journal of Social Psychology, 137, pp. 189-204.

Martin, B. and Simintiras, A.C. (1995), "The impact of green product lines on the environment: Does what they know affect how they feel?", Marketing Intelligence and Planning, 13 (4), pp. 16-23.

McCarty, J.A., \& Shrum, L.J. (1994), "The Recycling of Solid Wastes: Personal and Cultural Values and Attitudes about Recycling as Antecedents of Recycling Behaviour", Journal of Business Research, 30, pp. 53-62, available at http://dx.doi.org/10.1016/0148-2963(94) 90068-X.

McCarty, J.A., \& Shrum, L.J. (2001), "The Influence of Individualism, Collectivism, and Locus of Control on Environmental Beliefs and Behaviour", Journal of Public Policy \& Marketing, 20(1), pp. 93-104, available at http://dx.doi.org/10.1509/jppm.20.1.93.17291.

McDaniel, S. and Rylander, D. (1993), "Strategic green marketing", Journal of Consumer Marketing, 10, pp. 4-10.

Milfont, T. L. (2007), Psychology of Environmental Attitudes: A Cross-cultural Study of their Content and Structure, Unpublished doctoral dissertation, University of Auckland, Auckland, New Zealand.

Mostafa, M.M., (2007) "Gender differences in Egyptian consumers' green purchase behavior: The effects of environmental knowledge, concern and attitude", International Journal of Consumer Studies, 31: 220-229.

Nema R., (2011), “Green Buying Behavior In Indian Consumers Study”, available at MBASkool-Study.Learn.Share. 
Ottman, J.A. (2000), "It's not just the environment, stupid", available at www.greenmarketing.com/articles/IB_Sept00.html [August, 2004].

Ottman, J.A. and Terry, V. (1998), "Strategic marketing of greener products", available at from www.greenmarketing.com/articles/JSP1Apr98.html [December 2004].

Peattie, K. (1995), “Environmental marketing management”, London: Pitman Publishing.

Peattie, K. (2001), "Golden Goose or Wild Goose? The Hunt for the Green Consumer", Business Strategy and the Environment, 10, pp. 187-199, available at http://dx.doi.org/10.1002/bse.292.

Pujari, D. and Wright, G. (1996), "Developing environmentally-conscious product strategy: A qualitative study of selected companies in Britain and Germany", Marketing Intelligence and Planning, 14(1), pp. 19-28.

Roberts, J.A. (1996), "Green Consumers in the 1990s: Profile and Implications for Advertising" Journal of Business Research, 36, pp. 217-231, available at http://dx.doi.org/10.1016/0148-2963 (95)00150-6.

Roberts, J.A., \& Bacon, D.R. (1997), "Exploring the Subtle Relationships between Environmental Concern and Ecologically Conscious Consumer Behaviour", Journal of Business Research, 40(1), pp. 79-89, available at http://dx.doi.org/10.1016/S01482963(96)00280-9.

Schultz, P.W. and Zelezny, L.C. (2000), "Promoting environmentalism”, The Journal of Social Issues, 56, pp. 443-457.

Schultz, P.W., Shriver, C., Tabanico J.J. and Khazian, A.M. (2004), "Implicit connections with nature", Journal of Environmental Psychology, 24: 31-42.

Schwepker, C.H. and Cornwell, T.B. (1991), "An examination of ecologically concerned consumers and their intention to purchase ecologically packaged products", Journal of Public Policy and Marketing, 10, pp. 77-101.

Soonthonsmai, V. (2007), "Environmental and green marketing as global competitive edge: Concept, synthesis, and implication. EABR (business) and ETLC (teaching)", Conference Proceeding, Venice, Italy.

Straughan, R.D. and Robberts, J.A. (1999), "Environmental segmentation alternatives: A look at green consumer behavior in the new millennium" Journal of Consumer Marketing, 16(6), pp. 558-75.

Tesser, A. and Shaffer, D.R. (1990), "Attitudes and Attitude Change", Annual Review of Psychology, 41, pp. 479-523.

Thompson, C.J., Arsel, Z. (2004), "The Starbuck brandscape and consumers (anticorporate) experiences of globalisation", Journal of Consumer Research 31: 631-642.

Webb, D.J., Mohr, L.A. and Harris, K.E. (2008), “A re-examination of socially responsible consumption and its measurement", Journal of Business Research, 61: 91-98, available at www.censusindia.gov.in/2011-prov-results/prov_data_products_MP.html. 